This item was submitted to Loughborough's Research Repository by the author.

Items in Figshare are protected by copyright, with all rights reserved, unless otherwise indicated.

\title{
Motivations for servitization: the impact of product complexity
}

PLEASE CITE THE PUBLISHED VERSION

http://dx.doi.org/10.1108/IJOPM-09-2014-0447

\section{PUBLISHER}

(C) Emerald

\section{VERSION}

AM (Accepted Manuscript)

\section{PUBLISHER STATEMENT}

This work is made available according to the conditions of the Creative Commons Attribution-NonCommercialNoDerivatives 4.0 International (CC BY-NC-ND 4.0) licence. Full details of this licence are available at: https://creativecommons.org/licenses/by-nc-nd/4.0/

\section{LICENCE}

CC BY-NC-ND 4.0

\section{REPOSITORY RECORD}

Raddats, Chris, Tim Baines, Jamie Burton, Victoria Story, and Judy Zolkiewski. 2016. "Motivations for Servitization: The Impact of Product Complexity". Loughborough University. https://hdl.handle.net/2134/18679. 


\title{
Motivations for servitization: The impact of product complexity
}

Chris Raddats $^{\mathrm{a}}{ }^{*}$, Tim Baines ${ }^{\mathrm{b}}$, Jamie Burton ${ }^{\mathrm{c}}$, Vicky Story ${ }^{\mathrm{d}}$, Judy Zolkiewski ${ }^{\mathrm{c}}$

${ }^{a}$ Management School, University of Liverpool, Liverpool, UK

${ }^{\mathrm{b}}$ Aston Business School, Aston University, UK

${ }^{\mathrm{c}}$ Manchester Business School, University of Manchester, UK

${ }^{\mathrm{d}}$ School of Business and Economics, University of Loughborough, UK

* Corresponding author’s email: Chrisr@liv.ac.uk

\begin{abstract}
Purpose

To identify the commonalities and differences in manufacturers' motivations to servitize.

Design/methodology/approach
\end{abstract}

UK study based on interviews with 40 managers in 25 companies in 12 sectors. Using the concept of product complexity, sectors were grouped using the Complex Products and Systems (CoPS) typology: non-complex products, complex products, and systems.

\section{Findings}

Motivations to servitize were categorised as competitive, demand-based (i.e., derived from the customer) or economic. Motivations to servitize vary according to product complexity, although cost savings and improved service quality appear important demand-based motivations for all manufacturers. Non-complex product manufacturers also focus on services to help product differentiation. For CoPS manufacturers, both risk reduction and developing a new revenue stream were important motivations. For uniquely complex product manufacturers, stabilising revenue and increased profitability were strong motivations. For uniquely systems manufacturers, customers sought business transformation, whilst new service business models were also identified. 


\section{Research limitations/implications}

Using the CoPS typology, this study delineates motivations to servitize by sector. The findings show varying motivations to servitize as product complexity increases, although some motivational commonality existed across all groups.

Manufacturers may have products of differing complexity within their portfolio. To overcome this limitation the unit of analysis was the SBU.

\section{Practical implications}

Managers can reflect on and benchmark their motivation for, and opportunities from, servitization, by considering product complexity.

\section{Originality/value}

The first study to categorise servitization motivations by product complexity. Identifying that some customers of systems manufacturers seek business transformation through outsourcing. Keywords: capability, complexity, CoPS, motivation, resources, servitization Article Classification: Research paper 
Accepted for publication in the International Journal of Operations \& Production Management

\section{Introduction}

Interest in 'servitization' has grown rapidly over the last decade, with products and services increasingly being bundled together to improve value capture (Baines and Lightfoot, 2013; Vandermerwe and Rada, 1988). This servitization process has been likened to a ‘transformational journey', whereby a manufacturer seeks innovative capabilities and processes to create mutual value with customers (Neely, 2014, p. 107).

Many papers on this topic include a brief discussion of the motivations of manufacturers undertaking servitization; for example, Auramo and Ala-Risku (2005); Spring and Araujo (2013). These motivations generally draw on Wise and Baumgartner (1999) and are delineated by Oliva and Kallenberg (2003) into three main categories: competitive motivations, demandbased motivations, and economic motivations. Similarly, Baines et al. (2009) propose a typology based on: strategic (competitive), marketing (demand-based), and financial (economic) motivations.

Motivations for servitization can be explored for particular forms of service offering. Fischer et al. (2012) introduce: (1) Customer service to improve the quality of the customer relationship (demand-based motivations); (2) Product-related services (Services Supporting Products or SSPs [Mathieu, 2001]), to ensure the correct functioning of the product (competitive motivations); (3) Services supporting business needs (Services Supporting Clients or SSCs [Mathieu, 2001]), which support the operational needs of customers and enable new revenue streams to be developed (economic motivations). Similarly, motivations to servitize have also been aligned to service approaches of manufacturers. For example, Raddats and Kowalkowski (2014) introduce: (1) Services Doubters, for whom services are not a strong differentiator (low motivation); (2) Services Pragmatists, for whom services play an important role in product differentiation (average motivation); and (3) Services Enthusiasts, for whom services are both a differentiator and an enabler of growth (high motivation).

On reflection, these motivations for manufacturers to servitize are often assumed to be a truism and homogenous for all companies and sectors. In practice this is unlikely; circumstances will differ and this will have a profound effect on the servitization process. Therefore, the aim of this study is to explore the motivations to servitize, and identify commonalities and differences based on different degrees of product complexity. We use the Complex Products and Systems (CoPS) classification to help delineate between different degrees of product complexity, since complex products have generally been the context of most servitization studies to date. CoPS 
can be defined as 'high cost, engineering intensive products, systems, networks and constructs' (Ren and Yeo, 2006, p.521). Based on their classification, we focus on three degrees of complexity: systems, which are integrated combinations of complex products, for example, information technology (IT) and telecommunications; complex products, which are standalone offerings, for example, construction equipment, medical instruments; and non-complex products, which do not meet the CoPS classification criteria defined above, for example chemicals and metals (Ren and Yao, 2006).

The paper is structured to firstly present a theoretical framework (Section 2). This draws on resource-based theory (Barney, 1991; Hunt et al., 2006). The framework details the motivations to servitize in accordance with Oliva and Kallenberg's (2003) three motivations and a typology of product complexity based on a model proposed by Ren and Yeo (2006). Through this, we identify the study's research questions, which concern the differences between motivations to servitize between manufacturers based on product complexity. In section 3 we set out the research design, with the study based on forty in-depth interviews with managers in 25 companies. The results are presented and analysed in Section 4, which culminates in three research propositions. Section 5 sets out the theoretical contribution and the managerial implications of the study. The paper's conclusion is presented in Section 6, which includes limitations and avenues for future research.

\section{Literature Review}

\subsection{Resources and capabilities}

According to the Resource-Based View (RBV), firms are viewed as bundles of resources and capabilities that provide the basis for strategic competitive advantage, with companies needing to base their strategies on the resources and capabilities best suited to their markets (Barney, 1991). Given that firms might not own all the resources that confer competitive advantage, the RBV is not wholly appropriate to servitizing manufacturers (Kindström and Kowalkowski, 2014). We therefore draw on Resource-Advantage (R-A) theory, whereby firms seek to develop capabilities by combining resources, wherever they reside, in order to achieve superior financial performance and comparative advantage (Hunt et al., 2006).

Resources are defined as operand (an act or operation is performed on them) or operant (those that act or operate on other resources) (Madhavaram and Hunt, 2008). Operand resources are typically financial (e.g., cash), physical (e.g., plant, equipment) and legal (e.g., patents); whereas operant resources are typically human (e.g., skills of employees), organisational (e.g., 
culture), informational (e.g., knowledge from customers) and relational (e.g., establishing, developing and maintaining relationships with partners) (Hunt et al., 2006). Operant resources consist of specialised skills and knowledge and are viewed as central for firms to achieve competitive advantage (Hunt et al., 2006; Madhavaram and Hunt, 2008). Relational resources in particular enable firms to access the capabilities of other firms ('indirect capabilities') in order to achieve competitive advantage (Spring and Araujo, 2014).

A manufacturer will possess a unique combination of resources and capabilities, although it is unclear whether these will affect its motivations to servitize. Therefore, it is important to understand the motivations for servitization in order to fully understand the relevance and relative importance of the resources and capabilities that manufacturers either have, need to develop, or acquire.

\subsection{Motivations for servitization}

Competitive motivations suggest manufacturers view their products as their primary resource ('physical'), with services an important element of a differentiation strategy (Dachs et al., 2014). Even manufacturers in high-technology sectors and those focused on product innovation have found it increasingly difficult to differentiate their tangible products alone, with products increasingly becoming commodities as low-cost competitors aggressively price their tangible products to gain market share (Fischer et al., 2012). Services are, therefore, seen as an approach to creating competitive advantage and market differentiation (Raddats et al., 2015). Providing after-sales services can also enable manufacturers to better understand how their products perform in-service, enabling them to improve future product designs (Goffin and New, 2001).

In terms of demand-based motivations, Baines and Lightfoot (2013; 2014) characterise customer demands for services according to whether: customers undertake operational activities themselves; manufacturers provide some services; or manufacturers undertake the operational activity through an 'advanced' service. Even when customers undertake the activities themselves, there are still likely to be a number of 'base' services required from the manufacturer, such as product deliveries, spare part provision and warranties (Baines and Lightfoot, 2014). Customers may also want manufacturers to provide 'intermediate' services, such as a technical help-desk, training, maintenance, but still perform other service activities in-house. To meet rising customer demands, manufacturers are also finding it necessary to develop 'advanced' service offerings that can enable deeper customer relationships and address 
more complex requirements (Dachs et al., 2014); for example, risk/reward sharing (Baines and Lightfoot, 2014).

The drive for these advanced services comes from customers focusing on their core operations and outsourcing other business activities (Gebauer et al., 2010; Slack, 2005). Outsourcing allows the performance of these activities to be benchmarked against external providers' offerings, potentially leading to cost savings and improved service quality (Araujo and Spring, 2006). Suppliers that have already provided products are potentially well placed to win this business, since they already have an established relationship with the customer and perceived product expertise (Wise and Baumgartner, 1999).

Economic motivations are often central for manufacturers, with changing the corporate focus from products to services widely considered to be a route to economic success (Reinartz and Ulaga, 2008). This re-focusing process is akin to the latter stages of Oliva and Kallenberg's (2003) product-service continuum, involving new service business models (Kindström and Kowalkowski, 2014; Spring and Araujo, 2009). Services can deliver a new sustainable source of revenue to the manufacturer, helping it to overcome stagnating product markets (Eggert et al., 2011; Slack, 2005). The services market is often worth many times that of the product market, particularly as the installed product base increases (Auramo and Ala-Risku, 2005). Furthermore, sales of services are to some extent counter-cyclical to those of products, helping companies to avoid the peaks and troughs that are often associated with the sale of capital equipment (Gebauer and Fleisch, 2007; Slack, 2005).

Recent work offers some qualification of the idea that all firms might gain superior margins from the development of new services. Eggert et al. (2011) suggest that manufacturers with a broad service portfolio will benefit most from increasing profitability, with the higher costs associated with providing new services lowering profitability for manufacturers with a narrower range. Indeed, manufacturers may need to reach a critical mass of service activity (20-30\% of overall turnover) before the benefits of servitization are apparent in terms of firm value (Fang et al., 2008). Thus, the profitability of SSCs might be lower because customers decide to undertake the activities in-house or use lower-cost service providers (Gebauer et al., 2004). Manufacturers may not, therefore, necessarily benefit from moving 'downstream' to provide services due to the cost and upheaval involved (Davies, 2003).

Whilst these generic motivations for servitization have been extensively outlined in the extant literature (Baines et al., 2009), there is a lack of focus on whether motivations differ between 
different types of manufacturers (Raddats and Burton, 2014). For example, Neu and Brown's (2005) study of servitization within IT companies highlights the motivations pertinent to this sector, but makes little attempt to assess the generalisability of these motivations to other sectors. Fischer et al. (2012) only provide generic motivations for the capital goods sector. Auguste et al. (2006) delineate motivations to servitize as a decision to 'defend' the existing product business or 'grow' into new services markets, but no attempt was made to specify which companies should defend and which should grow. This study therefore seeks to address this limitation and develop a framework that delineates motivations between different types of manufacturer.

\subsection{CoPS and non-complex products}

The sectors most associated with servitization are those in which companies manufacture Complex Products and Services (CoPS), a sub-set of the capital goods market (Davies et al., 2007; Fischer et al., 2012). CoPS often have a high degree of component customisation to make the finished product or system (Acha et al., 2004; Davies et al., 2011). CoPS can be seen within the context of a Product-Service System (PSS) (Baines and Lightfoot, 2013), whereby the complexities in the former are also apparent, and are often greater, in the latter (Smith et al., 2014). This is particularly the case for use-orientated and results-orientated PSSs, where buyers will often seek collaborative relationships with suppliers to help manage this complexity (Howard and Caldwell, 2011).

Ren and Yeo (2006) suggest that the CoPS classification can be sub-divided into complex products and systems, with complex products being standalone entities and systems being complex products that are fully integrated in a system (Ren and Yeo, 2006). The distinction between a complex product and a system is, however, somewhat blurred, e.g., a train can be seen as a complex product but generally operates as part of a system (a network) (Ren and Yeo, 2006). The same distinction is also apparent for aerospace, IT and telecommunications products, where individual products are invariably combined into systems, fleets or networks. Thus, care needs to be taken when allocating cases to each category. To complete the typology, non-complex products do not meet the CoPS characterisation and include, for example, chemicals and fabricated metals.

Non-complex products have received less attention in the extant literature than CoPS (Lay et al., 2010). However, chargeable services were found to represent between 10-13\% of sales in sectors with simple products and those of medium complexity (Dachs et al., 2014). Thus, 
services are clearly important even for non-complex products, hence their inclusion in the study. Figure 1 provides a product typology based on complexity, whilst Appendix 1 identifies which sectors are classified as CoPS.

\section{Figure 1}

Manufacturers of CoPS have greater services opportunities than suppliers of other products (Dachs et al., 2014; Lay et al., 2010), but why might this be so? The nature of the contracts manufacturers of CoPS are asked to provide by customers offers some potential explanation, with buyers of CoPS increasingly seeking outcome-based contracts from their suppliers (Baines and Lightfoot, 2014; Neely et al., 2011). Thus, what might have been discrete transactions before servitization (e.g., the sale of a product and some 'base' or 'intermediate' services) become ongoing long-term relationships as part of an 'advanced' service after servitization (e.g., guaranteeing the availability of the product in an outcome-based service). Manufacturers offering outcome-based services, therefore, have to increase their focus on customer relationships since services success is dependent on co-production of the offering between the supplier and customer (Brax and Jonsson, 2009).

Complexity of the offering appears to be a variable that might delineate between the motivations for servitization, although the literature does not currently present a clear view on how this occurs. The conceptual framework, derived from current literature, is shown in Table 1.

\section{Table 1}

Thus, the overarching question for this study is: Do the motivations for servitization differ depending upon the complexity of the offering? This question will be answered by considering three sub-questions:

RQ1: What are the motivations to servitize for manufacturers of non-complex products?

RQ2: What are the motivations to servitize for manufacturers of complex products?

RQ3: What are the motivations to servitize for manufacturers of systems?

\section{Research Design}

\subsection{Data collection}

An exploratory study was undertaken, with qualitative in-depth interviews used to develop deep insights and help answer the three research questions. Given the study aimed to 
investigate motivations for servitization, manufacturers were selected for whom services appeared an important differentiator and value creator for their customers. We drew on data from 12 distinct sectors which have products with different degrees of complexity, with sector used as a proxy for product complexity (Dachs et al., 2014). A purposive sampling approach was used for data collection in order to select cases that provide sufficient levels of information for the topics being studied (Kemper et al., 2003). In particular, 'stratified purposive sampling' was applied, whereby the purposively selected target population was divided into strata, with the goal of discovering elements that are similar or different across the subgroups (Bryman, 2008); in this case, companies supplying non-complex products, complex products and systems.

The unit of analysis for the study was the Strategic Business Unit (SBU); relatively autonomous units controlling a number of their own functions (Homburg et al., 1999). The criteria for selecting the companies to study were: large companies (over £200M turnover per annum); classed as 'manufacturers' under the United Kingdom's (UK’s) Standard Industrial Classification (SIC) 2003; operated in the UK. A preliminary list was created of companies that met these criteria using the FAME database (Bureau van Dijk Electronic Publishing), which numbered around 450. These companies were then assessed to determine whether services played a significant part in their customer offerings. This was assessed through an analysis of company websites and financial reports, to give a target list of 40 firms, generally representing the most prominent companies in their sectors.

Potential interviewees within these organisations were primarily identified through using LinkedIn (LinkedIn Corporation) and company websites, and were contacted initially by letter, then email, then telephone. Interviewees were senior managers, responsible for their companies' services. In total, 40 managers were interviewed in 22 companies. In three of the companies the interviewees worked in SBUs operating in different market sectors, so effectively the total was 25 companies/SBUs (hereinafter termed companies) from 12 sectors. The interviewees worked in sales and marketing (20) or operations and services (20), and were senior managers (Director-level). Interviews were semi-structured and took place over a 6month period, predominantly in a face-to-face environment (31/40). The interviewees and the anonymised companies (and their sectors) that took part in the study are shown in Table 2.

Table 2 
The classification of 'complex product' or 'system' was based on the degree to which the products were combined into systems, fleets or networks within the companies under investigation. For companies classified as supplying systems there was clear evidence that each product was part of a greater whole. For companies classified as supplying complex products this was not the case. For example, whilst it might have been expected that the printers supplied by companies 12 and 13 would form part of a network system, in reality the printers were standalone and used for industrial purposes rather than networked office printers.

The preliminary research questions for the interviews were set out in an interview guide, based on the initial motivation themes derived from the literature (Table 1). The guide was tested on two managers from the population, who did not form part of the final sample. Each interview was recorded, transcribed and returned to the interviewee for validation (which 13 did). Interviews lasted on average one hour. This approach to data collection provided strong support for the internal validity of the study through the researchers being able to access interviewees’ knowledge and experience (Bryman, 2008).

\subsection{Data analysis}

Data analysis was undertaken using a template, which is a list of codes that represent the themes revealed from the data that has been collected (King, 2004). Template analysis is useful when comparing the perspectives of different groups within a specific context (King, 2004). The initial template (based on Table 1) comprised three primary motivations to servitize ('higher order' codes), and a number of drivers identified from the extant literature ('lower order' codes). In line with the use of template analysis, codes were then amended or added to as data was collected and analysed (Eisenhardt, 1989). Data analysis was undertaken using NVivo 7 (QSR International).

The final thematic coding structure was reached after an analysis of further transcripts brought forward neither new codes nor new relationships; that is, theoretical saturation was reached (Bryman, 2008). Coding the data enabled it to be aligned to the research questions, creating the final template presented in Section 4 (Table 3).

\section{Results and analysis}

In this section, each of the sub-questions is examined against the captured results.

\subsection{RQ1: What are the motivations to servitize for manufacturers of non-complex products?}


Accepted for publication in the International Journal of Operations \& Production Management

For many companies in non-complex product sectors there was a focus on using services to help differentiate products (competitive motivations). Typical responses from interviewees about their motivations to servitize were:

"Services have become more important for the mainstream (product) businesses that need to do more to differentiate themselves than by just using the product and price" (Company 4, Metals).

"Customers think of gas as a commodity but we try to get them to think of it more as a service. It is not a consumable product where you buy some gas, throw it away and buy some more. It isn't just about the product; it's the services around the product which are just as valuable as the product itself" (Company 2, Chemicals).

Product differentiation might also be achieved by offering faster delivery times through holding product stock, alleviating the need for customers to hold this stock (Company 4, Metals sector). When asked about the motivations to offer services, the manager in the aggregates sector noted:

"Giving the customer the right product, in the right place, at the right time, at the right price. This way we will be delivering value to customers" (Company 1, Aggregates).

Hence, services are not seen as a discrete activity but rather integral to the product offering. Demand-based motivations also appeared important to manufacturers of non-complex products, with cost reduction being particularly important:

"Cost is the main driver, with one element of this being headcount, so if a customer can get the same level of service from five suppliers as ten, they will go with this as the former might only require one person to manage them whereas the latter might require two" (Company 1, Aggregates).

In addition to cost reduction, improved service quality through engaging with product suppliers was seen as a critical requirement. This could involve ensuring the accuracy and timeliness of product deliveries ("on-time in-full” - Company 4, Metals). In line with their focus on differentiating via product availability, a number of companies were also motivated by their customers’ desire for improved service quality during the product’s operational life.

The data fails to reveal a significant focus on economic motivations, with companies generally not charging for services as a discrete offering, and the cost recovered via the product sale: 
Accepted for publication in the International Journal of Operations \& Production Management

“Technical Services (services linked to products) help a customer's production manager to test new products, solve production problems and formulate products for customers that are easy to use. Most of these services are free with payback through chemical sales” (Company 3, Chemicals).

The lack of direct economic motivation to offer services often means that companies selling non-complex products do not account for services revenue in isolation from product revenue. Instead, companies consider the product revenue that services are helping to secure, in this case for a facilities management service:

"The question is how much revenue that service is protecting. Putting a facilities manager on site locks that customer into [the company]. In other words, services protect the core business and retain high-value customers" (Company 2, Chemicals).

In summary, for manufacturers of non-complex products there is evidence supporting the importance of competitive and demand-based motivations, but little evidence supporting the importance of economic motivations, where these relate directly to services revenue and profitability. Services are thus an enabler and protector of product sales and a facilitator of improved customer relationships for these firms. This leads to the following research proposition (RP):

\section{RP1: Manufacturers of non-complex products have primarily competitive (product differentiation, competitor lock-out) and demand-based (cost savings, service quality) motivations for servitization.}

\subsection{RQ2: What are the motivations to servitize for manufacturers of complex products?}

There was little evidence that manufacturers of complex products have competitive motivations for offering services. In terms of demand-based motivations, several interviewees noted that customers required their product suppliers to undertake a range of service activities to help them save money, in order to lower the cost of product ownership:

"Clients would either like to save money or get more outputs with the same money" (Company 11, Medical instruments).

"Services are vital to minimise the cost of ownership and maximise the life of the machine” (Company 10, Construction). 
Accepted for publication in the International Journal of Operations \& Production Management

In addition to cost savings, improved service quality through engaging with product suppliers was seen as a critical requirement. This generally draws on a supplier's deep knowledge of the supplied products and ability to exploit economies of scale:

"Pipeline operators would not have the technology to do pipeline inspection and integrity themselves. It would require a whole engineering team, be costly, and most importantly they would still not be able to analyse the data themselves. In other words, the complexity of the services means that pipeline operators need to get specialist companies to do the work” (Company 7, Energy).

Even when the manufacturer does not sell directly to end customers but uses a dealer network, service quality is still critical. Company 9 employs a market research company to measure its customers' perceptions of service quality:

"The information from [market research company] can be used to determine whether there is a shortfall nationally, with a specific dealer or in a particular area of responsibility such as parts, warranty, reliability, quality. The survey measures factors that affect quality of service” (Company 9, Construction).

Engaging with suppliers to mitigate risks was also found to be an important customer requirement:

“On gas (power) stations for the newer technologies, the customers would probably want to outsource some of the work because of risk mitigation and management. However, for the older technologies they might want to do it themselves" (Company 6, Energy).

Economic motivations, particularly revenue growth, were also important for manufacturers of complex products:

"Services strategy has developed because of the need to grow the business faster than would be possible from products alone” (Company 10, Construction).

The cyclical nature of product revenue was also presented as a motivation for offering services:

“Our focus is on the 'recurring revenue business', to ensure that there is something built into each product to ensure recurring revenues” (Company 12, Printing).

There was also some agreement that services were a profitable part of the business (e.g., Company 8, Industrial Automation), although one company noted the risks of putting shortterm profits before long-term relationships: 
"There is a distinct difference between the health and sustainability of the business and its short-term financial performance. It is possible to fill the order book with loss-leading contracts or get very high percentage margin for one year, but this would result in never working on certain sites again because you would have become so contractual and engrained at making profits that you ruin relationships with clients” (Company 5, Energy).

In sum, manufacturers of complex products are not focused on competitive motivations, but rather focused on demand-based issues, such as helping customers lower the cost of product ownership and manage risk. Equally, economic motivations are key, with services seen to increase revenue, flatten the peaks and troughs associated with selling capital equipment and contribute to corporate profitability. This leads to the following RP:

\section{RP2: Manufacturers of complex products have primarily demand-based (cost savings, service quality, risk reduction) and economic (new revenue streams, stabilise revenue, greater profitability) motivations for servitization.}

\subsection{RQ3: What are the motivations to servitize for manufacturers of systems?}

For manufacturers of systems, there was no evidence of competitive motivations being relevant. In terms of demand-based motivations, customers were seeking ways to lessen the financial commitment of acquiring products; for example, switching capital expenditure (the purchase of IT equipment) to operational expenditure (a service-based contract) (Company 20, IT). This problem is acute in the aerospace/defence sector where governments, suffering from budget deficits, are less able to make outright acquisitions of military hardware:

"The customer was faced by a number of budgetary challenges and sought partnerships with their suppliers to address these” (Company 23, Aerospace/defense).

Improved service quality, cost reduction and risk mitigation, through engaging with product suppliers, were seen as critical requirements, drawing on a supplier's deep knowledge of the supplied products and ability to exploit economies of scale:

“We can do a customer's IT better than the customer, and if we don't think we can do it better we shouldn't be in the business. You create business value by doing things better and cheaper than the customers can do them within their own organisations” (Company 21, IT). 
Accepted for publication in the International Journal of Operations \& Production Management

"When (the customer) signed the original deal with us to do the maintenance it was considered their least risk option as they were buying cutting edge technology with a lot of new novel features” (Company 15, Transport).

Beyond these drivers, it was also clear that some customers were seeking systems to transform their businesses through engaging with their product suppliers:

“The (airline) operators' business models have changed, with the amount of outsourcing steadily climbing. Traditional carriers are doing this now, which has been prompted by low-cost carriers that have a clearly defined business model, with one of the premises being that they want minimal infrastructure and to be able to outsource it competitively” (Company 24, Aerospace/defence).

"Looking at the big players in the transport market for trams, buses, heavy rail, they are into all aspects of transport - they are not in it for the engineering. Fundamentally, they are there to get passengers onto their vehicles and collect fares" (Company 14, Transport).

The interviewees clearly drew a distinction between customer drivers related to outsourcing as cost reduction, risk and service quality and customers' desire for services to be provided as part of their own business transformation activities. These might take place through outsourcing, but are much more strategic drivers related to decisions about what their core offering is, or should be, and represent a more fundamental shift in the nature of a business:

"Every operator is doing some form of outsourcing, be it a small component or the whole thing. However, it is not just a matter of time, as operators will focus on their core business that they do best, with those elements of the business that could be done better by someone else, through efficiency, expertise or cost, being outsourced. This will vary by operator and the environment they operate in" (Company 16, Telecommunications).

The suggestion is that outsourcing is not a process that every customer will do to the same extent. A customer's perceptions of their core business will vary, so the supplier sees this variation and the different service opportunities that each provides, some transformational, some marginal (from the customer's perspective).

In terms of economic motivations, manufacturers see services as an approach to grow revenue when product markets are limited: 
Accepted for publication in the International Journal of Operations \& Production Management

"The strategy is being driven by a recognition that if you stick to own products and own services it is a limited marketplace, and typically unless you sell more boxes, year-on-year revenue will decline through discounts in years two and three" (Company 19, Telecommunications).

The proposition that services are a more profitable business than products was also challenged:

"In a business like ours, $80 \%$ of the revenue is from equipment, but $80 \%$ of the future growth will come from services and in the process you shift from high to much lower margins - it is therefore a challenge to keep both going” (Company 22, IT).

No manufacturer of systems mentioned increased profitability as a motivation for servitization. It might be, therefore, that when manufacturers of systems take over what were activities previously undertaken by customers themselves (SSCs), these are less (or no more) profitable than services closely linked to supporting their own products (SSPs), such as technical support. Rather than seeking increased profitability, providers of systems appear to view services as an opportunity to develop new service business models:

"The organisation moved towards being more of a 'Capgemini' type of organisation, with the product set being pulled in as and when it can to be part of a solution” (Company 19, Telecommunications).

Other companies have already adopted service business models. For example, Company 18 in the telecommunications sector has legacy products in its portfolio, but its focus is growing services around new multi-vendor platforms. This transformation was also apparent in the IT and aerospace/defence sectors:

"We started as a product business and have done the full migration to a services business, by strategy and choice” (Company 21, IT).

"As a group we decided that services were where we wanted to be, with discussions ongoing about the merger of our product with that of [competitor's] as a separate activity. This is part of our strategic objective to become a pure support services organisation” (Company 25, Aerospace/defense). 
Since the data was collected for this study, Company 25 has sold its product business to a competitor and merged its services business into a support services company specialising in military contracts, so completing the transition to a wholly service business model.

Manufacturers of systems appear to respond to a range of customer demands, from helping with the financial challenge of procuring capital equipment, to improving service processes and risk mitigation. Services also seem to enable manufacturers of systems and their customers to fundamentally change their business models. Customers are outsourcing non-core activities, ones that might not have been considered non-core a few years ago (e.g., the operations of a telecommunications network). Equally, some manufacturers of systems are becoming service providers, with products assuming a much less important role in their customer value propositions. This leads to the following RP:

\section{RP3: Manufacturers of systems have transformational motivations for servitization: new} service business models and customer business transformation. Other motivations are demand-based (cost savings, service quality, risk reduction) and economic (new revenue streams).

Table 3 sets out the motivations for servitization according to the complexity of the products (or system) supplied, with 'drivers' the basis for the motivation.

\section{Table 3}

\section{Discussion}

Overall, the results showed a positive response to the main research question: there was clear variation in the motivations for servitization identified for offerings of varying complexity. This study shows that whilst cost savings and improved service quality appear important demand-based motivations for all manufacturers, other motivations are particular to the type of products or system supplied. Product differentiation only appears applicable for manufacturers of non-complex products.

For suppliers of CoPS, cost savings, improved service quality and risk reduction (demandbased) and a new revenue stream (economic) appeared important motivations. Despite some common motivations, there were differences between complex products and systems. Most noteworthy are the transformational motivations of manufacturers of systems and their customers. To develop new service business models, manufacturers can replace their products with services as part of outcome-based offerings, whilst customers are able outsource some non-core operational activities to suppliers to focus on their core activities. How a customer 
defines what is core is also interesting; with some important but non-core activities (e.g., running IT systems) being outsourced by many businesses, and some operational aspects of the core activity (e.g., operating aeroplane engines) also outsourced. It therefore appears that it is not just how core the activity is to the business which determines whether it is outsourced, but also product complexity.

Manufacturers of complex products appeared more focused on stabilising revenue streams and increasing profitability through services than manufacturers of systems. Stabilising revenue streams becomes less of an issue for service-based contracts, so this is not surprising. For manufacturers of systems there is a realisation that services are not necessarily the best approach to increase profitability, since service-based offerings are not so dependent on being the OEM but are based on undertaking activities that could be run in-house by the customer, and therefore can be benchmarked for price and quality.

\subsection{Implications for theory}

Little attempt has been made in the extant literature to explore the motivations for servitization by distinguishing between different manufacturers. The aim of this study was to identify if there were differences in the motivations of manufacturers to undertake servitization, considering differences in the complexity of their products. This is the first time this comparison has been made and represents an important contribution of the study; namely, that although some commonalities exist, product complexity is a major influence on the motivations for servitization. Whilst the findings support Dachs et al. (2014), in that servitization is an important strategy for suppliers of CoPS, our results also show that servitization is highly relevant for suppliers of non-complex products.

A comparison of the conceptual framework (Table 1) and results from this study (Table 3) shows support for the motivations and drivers identified in the literature. However, the role of services as enablers of customers' strategic business transformation activities (a demand-based motivation), has not been previously identified. The comparison of Tables 1 and 3 also shows how the drivers align to the three degrees of complexity. This contrasts with previous research which barely recognises any differences in motivation based on product complexity or sector, beyond the greater opportunities with CoPS.

'Competitive' motivations are said to be the starting point for most companies undergoing servitization, with services used to help differentiate products (Eggert et al., 2013). This study suggests that these motivations are most appropriate for suppliers of non-complex products. 
Our findings, therefore, qualify the findings of Dachs et al. (2014), in that whilst competitive motivations are important they are not necessarily the main motivation for manufacturers of CoPS.

'Demand-based' motivations appear important for all manufacturers, with a particular focus on cost savings and improved service quality when an activity is outsourced (Araujo and Spring, 2006). For complex products, customers engage with product suppliers to help reduce risk (Company 6). This aligns to Baines and Lightfoot's (2014) second proposition, whereby customers require manufacturers to provide some services, potentially where the risks are highest, such as newer technologies. Customers procuring systems appear more likely to require 'advanced' services, such as availability or capability contracts (Baines and Lightfoot, 2014), to help facilitate business transformation (Gebauer et al., 2010). This might include relinquishing traditional engineering activities in favour of those centred on customer management and marketing, as was the case for customers of companies 15 (trains) and 24 (engines). There seems to be a real difference in the demands from customers in terms of outsourcing activities and how they relate to strategic or operational objectives. Therefore, suppliers must understand customer objectives so that they align their services appropriately.

'Economic' motivations appear to be most appropriate for suppliers of CoPS. For suppliers of complex products, this study shows that services represent an important approach to grow revenue (Oliva and Kallenberg, 2003), provide a more stable revenue stream (Wise and Baumgartner, 1999) and increased profitability (Dachs et al., 2014). When considering suppliers of systems, there was evidence of manufacturers being motivated by increased revenue through servitization, but no evidence that manufacturers were motivated by stabilising revenue or anticipated improved profitability through new service activities. Rather, there was an acceptance that services were where future growth would come from. This finding is at odds with some other studies which have emphasised the profit potential of SSCs (Mathieu, 2001), and highlights the importance of delineating between complex products and systems, since economic motivations differ between the two groups. To grow services revenue requires manufacturers of systems to look beyond SSPs and develop 'advanced' services (SSCs) which might be offered in competition with the customer undertaking the activities itself and new service competitors. Findings from this study, therefore, support previous studies that question the profit potential of SSCs (Eggert et al., 2011; Gebauer et al., 2004). The study has also highlighted how manufacturers of systems use services as an approach to develop new 
service business models (Companies 21 and 25) (supporting Kindström and Kowalkowski, 2014).

According to R-A theory companies combine resources in order to achieve superior financial performance and comparative advantage (Hunt et al., 2006). For manufacturers of noncomplex products, 'physical' resources (primarily their products) are central to their motivations to servitize. Motivations centre on product differentiation and meeting customer needs through providing excellent service quality and cost savings. For manufacturers of complex products, excellent service quality and cost savings are still important, but in addition 'relational' resources also become important, as customers seek closer links with their product suppliers to mitigate risk and potentially change their business focus through outsourcing. For manufacturers of systems, in addition to 'physical' and 'relational' resources, other operant resources are required. For example, 'human' resources (e.g., skilled service engineers capable of supporting products in an operational environment and account managers able to sell SSCs), 'organisational' resources (e.g., corporate leaders driving transformational change to a services culture) and 'informational' resources (e.g., having knowledge of customers' operational processes). Thus, as product complexity increases so the range of operant resources needed to successfully servitize also increases.

\subsection{Implications for management}

By considering the complexity of a manufacturer's product offerings, managers can better understand what their customers are likely to be looking for and what benefits they might expect from servitization efforts. Manufacturers of non-complex products focus on services as a means to differentiate products. These manufacturers could also respond to customer demands for cost savings through: coordinating the provision of other OEMs' products and services; delivering improved service quality, by assisting their customers with products in the operational environment. Whether services are charged for separately or as part of the product sale appears less important when services are primarily a product differentiator. Manufacturers of non-complex products might, however, also wish to develop a revenue stream from services, even if their products are not obviously amenable to service additions. In this case, the consequences of product failure could be stressed to customers and service offerings developed to help mitigate risk. Equally, re-positioning products from stand-alone entities to being part of a network or fleet might enable a manufacturer to provide chargeable services. 
Providers of complex products are likely to be motivated by customer demands for cost savings and improved service quality, but also risk reduction. Manufacturers providing complex products should be aware of the economic potential of services and avoid bundling the cost of services with the product sale, if this means that the value of services cannot be demonstrated to customers. Services can potentially provide these manufacturers with increased revenue, greater stability in revenue and increased profitability. Managers should, therefore, seek opportunities across their products' lifecycles to provide services; for example, product disposal. Developing services aligned to how products are used in the operational environment may not enable the same level of profitability as services guaranteeing product performance, if deep product knowledge becomes less of a differentiator.

Customers of system manufacturers are more likely to be seeking transformational services; for example, redefining their core businesses and outsourcing those areas no longer deemed core. This goes beyond cost saving and may mean that customers no longer wish to be involved in the engineering aspects of their products. System manufacturers need to be able to present a vision to customers of how their businesses might be transformed through outsourcing, and the part they can play in this transformation. Manufacturers of systems may also have the opportunity to focus their businesses on services, if customer demand and existing resources/capabilities allow. Although a possible strategic direction, this will not necessarily be appropriate for manufacturers with differentiated product portfolios which present strong opportunities for sales growth and profitability.

\section{Conclusion}

The motivations for servitization are often discussed in the extant literature but are rarely defined and analysed, and almost exclusively assumed to be homogeneous across all sectors. Manufacturers' motivations to servitize are generally characterised as competitive, demandbased and economic. Using the CoPS typology, three manufacturer groups have been assessed supplying: non-complex products, complex products and systems. With reference to these groups, differences in motivations were found based on product complexity. A manufacturer's motivations to servitize will ultimately be unique and dependent on a number of factors, but by considering the concept of product complexity, some commonalities for the three groups are revealed that have been captured into a new framework that has both academic and practical implications. The study extends our knowledge of why manufacturers servitize, with motivations to servitize differing based on product complexity. The work also identifies the 
need to look beyond the top-level categorisations in order to truly understand the drivers of a firm’s servitization efforts.

In common with other studies, this study has some limitations. Although the research was conducted on a large sample, the findings cannot be generalised to the population as the sample was purposively developed. Future research could take a confirmatory approach, based on the research propositions developed in this study, to provide further evidence. In this study there were proportionately more manufacturers supplying systems than complex products and, by a greater factor, non-complex products. However, the results clearly show that these firms can benefit from servitization activities in a number of key areas and more needs to be done to understand these non-complex product firms. Furthermore, managers in some sectors (e.g., aerospace/defence, IT, telecoms and transport) seemed more willing to participate in the study, and future research could aim to include more manufacturers from other sectors. The study also purposively sampled servitized manufacturers, and there would be value in studying manufacturers for whom services are less important, identifying reasons why this is the case and other factors which are more important.

Finally, some large manufacturers could have products with different levels of complexity. The unit of analysis for this study was the company or SBU (for the largest manufacturers), which was used to try to mitigate against this issue. However, future research could also investigate what other differences exist in the motivations to servitize between manufacturers, such as company size or geographic location. It could also explore whether motivations are equally related to performance outcomes of servitization efforts.

\section{Acknowledgements}

The authors would like to thank the two anonymous reviewers for comments on an earlier version of this paper. 


\section{References}

Acha, V., Davies, A., Hobday, M. and Salter, A. (2004), "Exploring the capital goods economy: Complex product systems in the UK", Industrial and Corporate Change, Vol. 13 No. 3, pp. 505-529.

Araujo, L. and Spring, M. (2006), "Services, products, and the industrial structure of production”, Industrial Marketing Management, Vol. 35 Iss. 7, pp. 797-805.

Auguste, B., Harmon, E. and Pandit, V. (2006). "The right service strategies for product companies", The McKinsey Quarterly, No. 1, pp. 40-51.

Auramo, J. and Ala-Risku, T. (2005), "Challenges for going downstream", International Journal of Logistics: Research and Applications, Vol. 8 No. 4, pp. 333-345.

Baines, T. and Lightfoot, H. (2014), "Servitization of the manufacturing firm. Exploring the operations practices and technologies that deliver advanced services”, International Journal of Operations \& Production Management, Vol. 34 No. 1, pp. 2-35.

Baines, T. and Lightfoot, H. (2013). Made to Serve. What it takes for a manufacturer to compete through servitization and Product-Service Systems', Wiley, Chichester, UK.

Baines, T., Lightfoot, H., Benedettini, O. and Kay, J. (2009), “The servitization of manufacturing. A review of literature and reflection on future challenges”, Journal of Manufacturing Technology, Vol. 20 No. 5, pp. 547-567.

Barney, J. (1991), "Firm resources and sustained competitive advantage", Journal of Management, Vol. 17 No. 1, pp. 99-120.

Brax, S. and Jonsson, K. (2009), "Developing integrated solution offerings for remote diagnostics. A comparative case study of two manufacturers”, International Journal of Operations and Production Management, Vol. 29 No. 5, pp. 539-560.

Bryman, A. (2008), Social Research Methods ( $3^{\text {rd }}$ ed.), Oxford University Press, Oxford, UK.

Dachs, B., Biege, S., Borowiecki, M., Lay, G., Jäger, A. and Schartinger, D. (2014), "Servitisation in European manufacturing industries: Empirical evidence from a large-scale database", The Service Industries Journal, Vol. 34 Iss. 1, pp. 5-23.

Davies, A. (2003), "Integrated solutions: the changing business of systems integration", in Prencipe, A. (Ed.), The Business of Systems Integration, Oxford University Press, New York, NY, pp. 333-368.

Davies, A., Brady, T. and Hobday, M. (2007), “Organizing for solutions: System seller vs. systems integrator”, Industrial Marketing Management, Vol. 36 No. 2, pp. 183-193.

Davies, A., Brady, T., Prencipe, A. and Hobday, M. (2011), "Innovation in complex products and systems: Implications for project-based organizing”, in Cattani, G. (Ed.), Project-based organizing and strategic management (Advances in Strategic Management), Vol. 28, pp. 326.

Eggert, A., Hogreve, J., Ulaga, W. and Muenkhoff, E. (2011), "Industrial services, product innovations, and firm profitability: A multiple-group latent growth curve analysis", Industrial Marketing Management, Vol. 40 No. 5, pp. 661-670. 
Eggert, A., Hogreve, J., Ulaga, W. and Muenkhoff, E. (2013), "Revenue and profit implications of industrial service strategies", Journal of Service Research, Vol. 17 No. 1, pp. 23-39.

Eisenhardt, K. (1989). “Building theories from case study research”, Academy of Management Review, Vol. 14 Iss. 4, pp. 532-550.

Fang, E., Palmatier, R. and Steenkamp, J. (2008), "Effect of service transition strategies on firm value”, Journal of Marketing, Vol. 72 No. 4, pp. 1-14.

Fischer, T., Gebauer, H. and Fleisch, R. (2012), Service Business Development: Strategies for Value Creation in Manufacturing Firms, Cambridge University Press: Cambridge, UK.

Gebauer, H., Beckenbauer, B. and Fleisch, E. (2004), "How to innovate customer support services in manufacturing firms?", in Edvardsson, B., Gustafsson, A., Brown, S. and Johnston, R. (Eds.), proceedings of the QUIS 9 Conference, 2004, Karlstad University Press: Karlstad, Sweden, pp. 397-406.

Gebauer, H., Edvardsson, B., Gustafsson, A. and Witell, L. (2010), "Match or mismatch: strategy configurations in the service business of manufacturing companies", Journal of Service Research, Vol. 13 No. 2, pp. 198-215.

Gebauer, H and Fleisch, E. (2007), “An investigation of the relationship between behavioural processes, motivation, investments in the service business and service revenue”, Industrial Marketing Management, Vol. 36 Iss. 3, pp. 337-348.

Goffin, K. and New, C. (2001), "Customer support and new product development - an exploratory study”, International Journal of Operations \& Production Management, Vol. 21 No. 3, pp. 275-301.

Homburg, C., Workman, J. and Krohmer, H. (1999), “Marketing’s influence within the firm”, Journal of Marketing, Vol. 63 No. 2, pp. 1-17.

Howard, M. and Caldwell, N. (2011), “Introduction”, in Caldwell, N. and Howard, M. (Eds.), Procuring Complex Performance: Studies of Innovation in Product Service Management, Routledge, New York, NY.

Hunt, S., Arnett, D. and Madhavaram, S. (2006), "The explanatory foundations of relationship marketing theory", Journal of Business \& Industrial Marketing, Vol. 21 No. 2, pp. 72-87.

Kemper, E., Stringfield, S. and Teddlie, C. (2003). "Mixed methods sampling strategies in social science research”, in Tashakkori, A. and Teddlie, C. (Eds.), Handbook of Mixed Methods in Social and Behavioural Research, Sage: Thousand Oaks, CA, Ch. 10.

Kindström, D. and Kowalkowski, C. (2014), "Service innovation in product-centric firms: A multinational business model perspective”, Journal of Business \& Industrial Marketing, Vol. 29 Iss. 2, pp. 96-111.

King, N. (2004), "Using templates in the thematic analysis of texts" in Cassell, C. and Symon. G. (Eds.), Essential guide to qualitative methods in organizational research, Sage, London, UK, pp. 256-70.

Lay, G., Copani, G., Jäger, A. and Biege, S. (2010), “The relevance of service in European manufacturing industries”, Journal of Service Management, Vol. 21 No.5, pp. 715-726.

Madhavaram, S. and Hunt, S. (2008). "The service-dominant logic and a hierarchy of operant resources: Developing masterful operant resources and implications for marketing strategy”, Journal of the Academy of Marketing Science, Vol. 36 Iss. 1, pp. 67-82. 
Mathieu, V. (2001), "Product services: From a service supporting the product to a service supporting the client", Journal of Business \& Industrial Marketing, Vol. 16 No. 1, pp. 39-61.

Neely, A. (2014), “Society's grand challenges: What role for services?”, in Haynes, K. and Grugulis, I. (Eds.), Managing Services. Challenges and Innovation, Oxford University Press, Oxford, UK, pp. 105-121.

Neely, A., Benedettini, O. and Visnjic, I. (2011), “The servitization of manufacturing: Further evidence”, paper presented at the EuOMA Conference, Cambridge. Available at: http://www.cambridgeservicealliance.org/outputs/papers.html (accessed 11th October 2014).

Neu, W. and Brown, S. (2005), "Forming successful business-to-business services in goodsdominant firms", Journal of Service Research, Vol. 8 No. 1, pp. 3-17.

Oliva, R. and Kallenberg, R. (2003), "Managing the transition from products to services", International Journal of Service Industry Management, Vol. 14 No. 2, pp. 160-172.

Raddats, C. and Burton, J. (2014), “Creating multi-vendor solutions: The resources and capabilities required”, Journal of Business \& Industrial Marketing, Vol. 29 No. 2, pp. 132142.

Raddats, C., Burton, J. and Ashman, R. (2015), "Resource configurations for services success in manufacturing companies”, Journal of Service Management, Vol. 26 Iss. 1, pp. 97-116.

Raddats, C. and Kowalkowski, C. (2014), “A reconceptualization of manufacturers' services strategies”, Journal of Business-to-Business Marketing, Vol. 21 Iss. 1, pp. 19-34.

Reinartz, W. and Ulaga, W. (2008), "How to sell services profitably”, Harvard Business Review, Vol. 86 Iss. 5, pp. 90-96.

Ren, Y. and Yeo, K. (2006), "Research challenges on complex product systems (CoPS) innovation”, Journal of the Chinese Institute of Industrial Engineers, Vol. 23 Iss. 6, pp. 519529.

Slack, N. (2005), “Operations strategy: Will it ever realise its potential?”, Gestão \& Produção, Vol. 12 No. 3, pp. 323-332.

Smith, L., Maull, R. and Ng, I. (2014), "Servitization and operations management: A service dominant-logic approach”, International Journal of Operations \& Production Management, Vol. 34 No. 2, pp. 242-269.

Spring, M. and Araujo, L. (2009), "Service, services and products: Rethinking operations strategy”, International Journal of Operations \& Production Management, Vol. 29 No. 5, pp. 444-467.

Spring, M. and Araujo, L. (2013), "Beyond the service factory: Service innovation in manufacturing supply networks”, Industrial Marketing Management, Vol. 42 Iss. 1, pp. 5970 .

Spring, M. and Araujo, L. (2014), "Indirect capabilities and complex performance. Implications for procurement and operations strategy", International Journal of Operations \& Production Management, Vol. 34 No. 2, pp. 150-173.

UK Standard Industrial Classification (SIC) of Economic Activities (2003), available at: http://www.businessballs.com/industrialclassifications.htm (accessed 14th April 2014).

Vandermerwe, S. and Rada, J. (1988), "Servitization of business: Adding value by adding services", European Management Journal, Vol. 6, pp. 314-324. 
Accepted for publication in the International Journal of Operations \& Production Management

Wise, R. and Baumgartner, P. (1999), "Go downstream: The new profit imperative in manufacturing ", Harvard Business Review, Vol. 77 No. 5, pp. 133-141. 


\section{Appendix 1- Complex Products and Systems (CoPS)}

\begin{tabular}{|c|c|}
\hline $\begin{array}{l}\text { SIC 3- } \\
\text { dig code }\end{array}$ & Industries \\
\hline 282 & Manufacture of tanks, reservoirs and containers of metals \\
\hline 283 & Manufacture of steam generators, except central heating hot water boilers \\
\hline 291 & $\begin{array}{l}\text { Manufacture of engines and turbines, except aircraft, vehicles and cycle engines } \\
\text { Manufacture of pumps; compressors }\end{array}$ \\
\hline 292 & $\begin{array}{l}\text { Manufacture of non-domestic cooling and ventilation equipment } \\
\text { Manufacture of other general purpose machinery }\end{array}$ \\
\hline 293 & Manufacture of agricultural and forestry machinery \\
\hline 294 & Manufacture of machine tools \\
\hline 295 & $\begin{array}{l}\text { Manufacture of machinery for metallurgy } \\
\text { Manufacture of machinery for mining; earth-moving equipment; equipment for } \\
\text { concrete crushing and screening and roadworks } \\
\text { Manufacture of machinery for food, beverage and tobacco processing } \\
\text { Manufacture of machinery for paper and paperboard production } \\
\text { Manufacture of other special purpose machinery }\end{array}$ \\
\hline 296 & Manufacture of weapons and ammunition \\
\hline 300 & Manufacture of office machinery and computers \\
\hline 316 & Manufacture of other electrical equipment \\
\hline 322 & $\begin{array}{l}\text { Manufacture of telegraph and telephone apparatus and equipment: radio and } \\
\text { electronic capital goods }\end{array}$ \\
\hline 331 & Manufacture of medical and surgical equipment and orthopaedic appliances \\
\hline 332 & $\begin{array}{l}\text { Manufacture of electronic and non-electronic instruments and appliances for } \\
\text { measuring, checking, testing, navigating and other purposes }\end{array}$ \\
\hline 333 & $\begin{array}{l}\text { Manufacture of electronic sand non-electronic industrial process control } \\
\text { equipment }\end{array}$ \\
\hline 334 & $\begin{array}{l}\text { Manufacture of spectacles and unmounted lenses; optical precision instruments; } \\
\text { photographic and cinematic equipment }\end{array}$ \\
\hline 351 & Building and repairing of ships \\
\hline 352 & Manufacture of railway and tramway locomotives and rolling stock \\
\hline 353 & Manufacture of aircraft and spacecraft \\
\hline 452 & $\begin{array}{l}\text { General construction of buildings and civil engineering works } \\
\text { Construction of highways, roads, airfields and sports facilities, water projects }\end{array}$ \\
\hline
\end{tabular}

Based on UK Standard Industrial Classification (SIC) 92 (Acha et al., 2004, pp.526-528) 


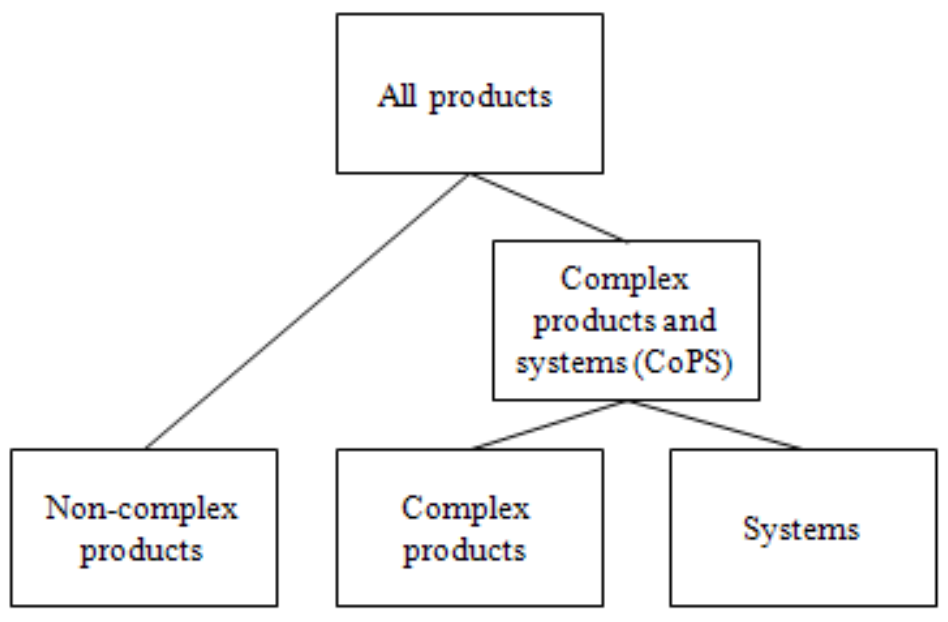

Figure 1: Hierarchy of products (adapted from Ren and Yao, 2006, p. 523) 


\begin{tabular}{|c|c|c|c|c|c|}
\hline \multirow[t]{2}{*}{ Driver } & \multirow[t]{2}{*}{ Source(s) } & \multirow[t]{2}{*}{$\begin{array}{l}\text { Explanation of } \\
\text { driver }\end{array}$} & \multicolumn{2}{|c|}{$\begin{array}{c}\text { Product } \\
\text { complexity }\end{array}$} & \multirow{2}{*}{$\begin{array}{c}\text { Motivation } \\
\text { for } \\
\text { servitization } \\
\text { (Oliva and } \\
\text { Kallenberg, } \\
\text { 2003) }\end{array}$} \\
\hline & & & $\begin{array}{c}\text { Non- } \\
\text { complex } \\
\text { products }\end{array}$ & CoPS & \\
\hline $\begin{array}{l}\text { Product } \\
\text { differentiation }\end{array}$ & Mathieu (2001) & $\begin{array}{l}\text { Creates a stronger } \\
\text { value proposition } \\
\text { than products } \\
\text { alone }\end{array}$ & $X$ & & Competitive \\
\hline Cost savings & $\begin{array}{l}\text { Araujo and } \\
\text { Spring (2006) }\end{array}$ & $\begin{array}{l}\text { Saving the } \\
\text { customer money } \\
\text { in terms of } \\
\text { product } \\
\text { ownership }\end{array}$ & & $X$ & \multirow{3}{*}{ Demand-based } \\
\hline $\begin{array}{l}\text { Improved } \\
\text { service quality }\end{array}$ & $\begin{array}{l}\text { Araujo and } \\
\text { Spring (2006); } \\
\text { Fischer et al., } \\
\text { (2012) }\end{array}$ & $\begin{array}{l}\text { Improvements in } \\
\text { customer } \\
\text { operational } \\
\text { processes }\end{array}$ & & 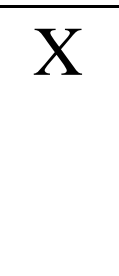 & \\
\hline Risk reduction & $\begin{array}{l}\text { Baines and } \\
\text { Lightfoot (2014) }\end{array}$ & $\begin{array}{l}\text { Sharing new } \\
\text { technology } \\
\text { introduction and } \\
\text { operational } \\
\text { performance risk }\end{array}$ & & $X$ & \\
\hline $\begin{array}{l}\text { New revenue } \\
\text { stream }\end{array}$ & Mathieu (2001) & $\begin{array}{l}\text { Services provide } \\
\text { incremental } \\
\text { revenue to } \\
\text { product revenue }\end{array}$ & & $X$ & \\
\hline $\begin{array}{l}\text { Stabilise } \\
\text { revenue }\end{array}$ & $\begin{array}{l}\text { Gebauer and } \\
\text { Fleisch, (2007); } \\
\text { Slack (2005) }\end{array}$ & $\begin{array}{l}\text { Services revenue } \\
\text { less liable to } \\
\text { fluctuate than } \\
\text { product revenue }\end{array}$ & & $\mathrm{X}$ & Economic \\
\hline
\end{tabular}


Accepted for publication in the International Journal of Operations \& Production Management

\begin{tabular}{|l|l|l|l|l|}
\hline $\begin{array}{l}\text { Increased } \\
\text { profitability }\end{array}$ & $\begin{array}{l}\text { Oliva and } \\
\text { Kallenberg (2003) }\end{array}$ & $\begin{array}{l}\text { Higher } \\
\text { profitability } \\
\text { attributable to } \\
\text { service activities }\end{array}$ & X & \\
\hline $\begin{array}{l}\text { New service } \\
\text { business } \\
\text { model }\end{array}$ & $\begin{array}{l}\text { Kindström and } \\
\text { Kowalkowski, } \\
\text { (2014); Spring } \\
\text { and Araujo } \\
\text { (2009) }\end{array}$ & $\begin{array}{l}\text { Manufacturers } \\
\text { able to develop } \\
\text { service offerings } \\
\text { that replace } \\
\text { product offerings }\end{array}$ & X & \\
\hline
\end{tabular}

Table 1: Motivations to servitize (in the servitization literature) 


\begin{tabular}{|c|c|c|c|c|}
\hline \multirow[t]{2}{*}{ Company } & \multirow{2}{*}{$\begin{array}{l}\text { Number of } \\
\text { interviewees }\end{array}$} & \multicolumn{2}{|c|}{ CoPS classification } & \multirow[t]{2}{*}{ (sector) } \\
\hline & & $\begin{array}{l}\text { Non-complex } \\
\text { products }\end{array}$ & $\begin{array}{l}\text { Complex } \\
\text { products }\end{array}$ & \\
\hline 1 & 1 & Aggregates & & \\
\hline 2 & 2 & Chemicals & & \\
\hline 3 & 2 & Chemicals & & \\
\hline 4 & 2 & Metals & & \\
\hline $5(a)$ & 1 & & Energy & \\
\hline 6 & 1 & & Energy & \\
\hline 7(b) & 1 & & Energy & \\
\hline $8(\mathrm{c})$ & 1 & & $\begin{array}{l}\text { Industrial } \\
\text { automation }\end{array}$ & \\
\hline 9 & 2 & & $\begin{array}{l}\text { Construction } \\
\text { equipment }\end{array}$ & \\
\hline 10 & 2 & & $\begin{array}{l}\text { Construction } \\
\text { equipment }\end{array}$ & \\
\hline 11(b) & 1 & & $\begin{array}{l}\text { Medical } \\
\text { instruments }\end{array}$ & \\
\hline 12 & 2 & & Printing & \\
\hline 13 & 2 & & Printing & \\
\hline 14 (c) & 1 & & & Transport (trains) \\
\hline $15(a)$ & 1 & & & Transport (trains) \\
\hline 16 & 2 & & & Telecommunications \\
\hline 17 & 1 & & & Telecommunications \\
\hline 18 & 1 & & & Telecommunications \\
\hline 19 & 2 & & & Telecommunications \\
\hline 20 & 2 & & & IT \\
\hline 21 & 2 & & & IT \\
\hline 22 & 2 & & & IT \\
\hline 23 & 2 & & & Aerospace/defence \\
\hline 24 & 2 & & & Aerospace/defence \\
\hline 25 & 2 & & & Aerospace/defence \\
\hline
\end{tabular}

Table 2: Companies that took part in the study

Note: SBUs within the same company are indicated by the same letter (a, b, c) 
Accepted for publication in the International Journal of Operations \& Production Management

\begin{tabular}{|c|c|c|c|c|}
\hline & \multicolumn{3}{|c|}{ Product complexity } & \multirow[b]{2}{*}{$\begin{array}{c}\text { Motivation for } \\
\text { servitization }\end{array}$} \\
\hline Driver & $\begin{array}{c}\text { Non- } \\
\text { complex } \\
\text { products }\end{array}$ & $\begin{array}{l}\text { Complex } \\
\text { products }\end{array}$ & Systems & \\
\hline $\begin{array}{l}\text { Product } \\
\text { differentiation }\end{array}$ & $X$ & & & Competitive \\
\hline Cost savings & $\mathrm{X}$ & $\mathrm{X}$ & $X$ & \multirow{4}{*}{ Demand-based } \\
\hline $\begin{array}{l}\text { Improved } \\
\text { service quality }\end{array}$ & $X$ & $X$ & $\mathrm{X}$ & \\
\hline Risk reduction & & $\mathrm{X}$ & $X$ & \\
\hline $\begin{array}{l}\text { Customer } \\
\text { business } \\
\text { transformation }\end{array}$ & & & X & \\
\hline $\begin{array}{l}\text { New revenue } \\
\text { stream }\end{array}$ & & $X$ & $\bar{X}$ & \multirow{4}{*}{ Economic } \\
\hline $\begin{array}{l}\text { Stabilise } \\
\text { revenue }\end{array}$ & & $X$ & & \\
\hline $\begin{array}{l}\text { Increased } \\
\text { profitability }\end{array}$ & & $X$ & & \\
\hline $\begin{array}{l}\text { New service } \\
\text { business model }\end{array}$ & & & $X$ & \\
\hline
\end{tabular}

Table 3: Motivations to servitize based on product complexity 